\title{
PENDEKATAN PROBLEM-BASED LEARNING DALAM PEMBELAJARAN PRAKTIK KERJA LAPANGAN TERAPI FISIK
}

\author{
B.M.Wara Kushartanti \\ (FIK Universitas Negeri Yogyakarta, HP: 08122943398 \\ e-mail: bm_warakushartanti@uny.ac.id)
}

\begin{abstract}
The Problem-Based Learning Approach in Physical Therapy Field Works. The objectives of the study are to identify strategic application of ProblemBased Learning (PBL) in physical therapy field works and to improve students' mastery in physical therapy in terms of cognitive, affective, and psychomotor domains. This action research study consisted of three cycles, each of which included four stages, namely planning, implementing the plan, monitoring activities and progress, and reflection. The participants were 23 seventh semester students taking physical therapy field works in 2007. In the first cycle, students' theoretical mastery was inadequate. In the second cycle they did more extensive literature search to expand theories. In the third cycle they learned more about empirical cases, not just theories, so that they better skills in implementing the whole PBL activities and managed to attain the course objectives. PBL is therefore suitable for advanced students prior to their professional development.
\end{abstract}

Keywords: problem based-learning, physical therapy field works

\section{PENDAHULUAN}

Pendekatan Problem-Based Learning (PBL) merupakan pendekatan yang menekankan pada terpaparnya masalah sebagai pemicu belajar, sehingga belajar tidak lagi terkotak-kotak menurut bidang ilmu, tetapi terintegrasi secara keseluruhan (Gagne, 1985:35). Pendekatan ini sangat tepat digunakan sebagai strategi mengajar pada matakuliah terapan yang bertujuan untuk membantu mahasiswa agar siap memasuki dunia kerja, termasuk matakuliah Praktik Kerja Lapangan (PKL). Pendekatan ini juga relevan dengan prinsip belajar yang dikemukakan oleh Davies (1997:56), yaitu bahwa mahasiswa harus aktif, ritme pembelajaran harus sesuai dengan ting- kat kemampuannya, penguatan perlu diberikan secara langsung, dan perlu juga diberi tanggung jawab serta kepercayaan penuh atas belajarnya.

Di samping itu, pendekatan Problem Based Learning juga relevan dengan hasil penelitian Thornburg pada tahun 1984 tentang retensi, yang antara lain menyatakan bahwa retensi akan lebih baik pada materi yang bersifat kontekstual. Meskipun demikian, Alessio (2002: 3), mendapatkan perbedaan yang tidak signifikan pada hasil ujian antara kelas yang diberi metode pengajaran tradisionaldan kelas PBL. Respon mahasiswa yang antusias terhadap metode PBL ditemukan dalam penelitian Mierson (2004:3). Antusiasme yang sama juga 
didapatkan oleh Kelsner (2001:2) dengan penerapannya pada siswa SMA yang kesulitan belajar.

Penelitian yang dilakukan di Middlebex University (2002:4) tentang keefektifan metode PBL mendapatkan fakta bahwa metode ini digunakan secara luas sebagai metode pilihan untuk pendidikan profesional, seperti pendidikan dokter, keperawatan, dan kebidanan. Keefektifan metode PBL sangat tergantung pada desain penelitian yang digunakan. Dengan PBL, peserta didik mempunyai kemampuan adaptasi, problem solving, membuat pertimbangan yang rasional, melakukan pendekatan yang menyeluruh dan universal, mengembangkan empati, dan bekerja dalam tim.

Ada konsensus umum tentang keefektifan berbagai metode pengajaran, yang disarikan dalam bentuk piramida pembelajaran (learning pyramid) yang dipublikasikan oleh Bligh (1998) dalam Wood (2004:1). Di situ digambarkan bahwa kuliah metode konvensional adalah yang terburuk, karena umumnya mahasiswa mencatat dan mengulanginya sesaat sebelum ujian dan melupakan apa yang sudah dipelajari dalam waktu singkat. Dikatakan kemampuan mempertahankan informasi hanya $5 \%$. Sebaliknya, metode pembelajaran di dasar piramid jauh lebih efektif, yaitu dengan saling membagi informasi di antara peserta didik, belajar dengan melakukan praktik langsung dan diskusi kelompok. Aktivitas-aktivitas inilah yang djalankan selama proses PBL. Dalam PBL, upaya-upaya intelektual dicapai dalam level yang lebih tinggi dalam taksonomi Bloom, yaitu sampai tahapan aplikasi, bagaimana menggunakan pengetahuan, mendemonstrasikan, dan mempraktikkannya.

Mata kuliah Praktik Kerja Lapangan (PKL) merupakan mata kuliah yang ditujukan untuk mendekatkan mahasiswa pada lapangan kerja sehingga mahasiswa tidak gagap kerja setelah lulus. Sesuai dengan kompetensi yang telah dirumuskan, maka setelah menyelesaikan PKL Terapi Fisik, mahasiswa harus mampu merancang program terapi fisik baik untuk pasien cedera maupun penyakit degeneratif (Diabetes Mellitus, Hipertensi, Asma, dan Penyakit Jantung). Pada observasi yang dilakukan sebelum penelitian terlihat bahwa pada saat terjun menangani pasien, mahasiswa sering "blocking" tidak tahu apa yang harus dilakukan, sehingga menimbulkan keraguan pasien terhadap kemampuannya. Keraguan dan ketidakpercayaan pasien semakin membuat mahasiswa tidak tahu apa yang harus dilakukan. Dari 20 mahasiswa PKL pada tahun 2006 semua mengakui adanya ketidaktahuan tentang apa yang harus dilakukan. Pengamatan dan wawancara mendalam yang dilakukan terhadap mahasiswa mendapatkan adanya pola pikir yang dimulai dari teori untuk kemudian diaplikasikan dalam menangani pasien. Dengan pola pikir demikian, mereka cenderung memandang dengan wawasan teori yang sempit, sehingga menghasilkan pemecahan masalah yang sempit pula.

Perlu dicoba untuk membalik pola pikir dengan memulai dari masalah nyata yang dihadapi, kemudian dipikirkan berbagai alternatif penyebab maupun jalan keluarnya. Pada saat berpikir 
alternatif,mahasiswa dipaksa untuk memandang dari berbagai sudut dengan teori dan konsep dasar yang lebih luas. Pendekatan Problem-Based Learning memungkinkan untuk itu karena PBL merupakan suatu pendekatan pembelajaran yang menggunakan problem/masalah sebagai sumber atau dasar pembelajaran. Dosen berperan sebagai perancang dan fasilitator. Mahasiswa aktif mengeksplorasi problem dan bekerja sama untuk mendiskusikan serta mendapatkan jalan keluar dari problem tersebut (Barrows, 2001). Penerapan PBL dalam berbagai mata kuliah dan tingkatan ternyata sangat bervariasi, tergantung pada bidang ilmu dan karakteristik masalah. Dengan dasar inilah maka perlu dicari strategi penerapan PBL dalam mata kuliah PKL Terapi Fisik agar sampai pada tujuan untuk mempersiapkan mahasiswa memasuki dunia kerja dalam bidang Terapi Fisik. Pencarian strategi tersebut akan lebih bisadipertanggungjawabkan apabila dikemas dalam bingkai penelitian.

Dengan diketahuinya strategi penerapan Problem-Based Learning dalam mata kuliah PKL Terapi Fisik diharapkan dapat menjadi pertimbangan dalam penerapannya pada mata kuliah lain yang sejenis. Di samping itu, penerapan penelitian tindakan diharapkan akan meningkatkan hal-hal sebagai berikut: (1) kemampuan mahasiswa untuk berpikir kritis dan menyeluruh dalam memecahkan masalah nyata di lapangan; (2) pemahaman mahasiswa akan berbagai konsep dasar yang menjadi pegangan untuk memecahkan masalah nyata di lapangan; dan (3) kesiapan mahasiswa untuk terjun di lapangan pekerjaan de- ngan mengangkat problem nyata di lapangan sebagai sumber belajar. Berbagai peningkatan diatas akan memberi manfaat antara lain: (1) meningkatkan kepercayaan diri mahasiswa untuk terjun di dunia kerja sesuai dengan kompetensinya; (2) membantu mahasiswa mengkristalkan, menghubungkan, dan mengaplikasikan berbagai mata kuliah yang telah dipelajarinya; (3) merangsang mahasiswa untuk aktif mencari informasi, mengkomunikasikan informasi dan pemikirannya kepada orang lain; (4) meningkatkan keterampilan untuk bekerjasama, memformulasikan problem, membuat keputusan dan menarik kesimpulan.

\section{METODE}

Penelitian ini merupakan penelitian tindakan kelas yang terdiri atas tiga siklus. Masing-masing siklus terdiri atas kegiatan perencanaan tindakan, pelaksanaan tindakan, monitoring atau observasi, dan refleksi. Hasil refleksi pada siklus I akan menentukan langkah pada siklus berikutnya, dan demikian selanjutnya sehingga didapatkan keberhasilan sesuai dengan kriteria yang ditentukan.

Subjek penelitian adalah mahasiswa Program Studi Ilmu Keolahragaan yang mengikuti PKL Terapi Fisik pada semester ganjil 2007 sejumlah 23 orang. Prosedur penelitian dimulai dengan perencanaan tindakan pada siklus I yang terdiri atas kegiatan sebagai berikut: (1) melakukan wawancara mendalam untuk mengungkap persepsi mahasiswa terhadap matakuliah PKL, dan harapan mahasiswa terhadap mata kuliah tersebut, baik dalam proses maupun da- 
lam hasil; (2) menganalisis hasil pengungkapan tersebut; (3) mengemukakan rencana eksplorasi problem dan metode perkuliahan yang akan dilakukan, termasuk rencana tempat PKL sebagai sumber problem; (4) menyepakati dan menyatubahasakan tujuan, sasaran, materi, dan metode perkuliahan yang akan dilakukan; (5) menyiapkan paparan problem dengan segala perangkatnya.

Dengan rencana tindakan tersebut, dilaksanakan tindakan memimpin diskusi kasus dengan problem/masalah yang didapatkan dari pasien di Klinik Terapi Fisik dan menggunakan pendekatan "Problem-Based Learning". Selama tindakan, diadakan pengamatan menggunakan lembar pengamatan untuk mengevaluasi antusiasme dan keaktifan peserta kuliah, serta memberi pertanyaan untuk mengungkap besarnya serapan mata kuliah selama siklus I. Selanjutnya, dilakukan refleksi dengan cara menganalisis hasil pengamatan, dan jawaban tertulis dari mahasiswa, mengevaluasi kelemahan dan kekuatan yang ada, dan mencari jalan keluar untuk mengatasi kelemahan tersebut. Kriteria keberhasilan yang ingin dicapai adalah penguasaan ilmu dan keterampilan dalam menangani problem yang dikeluhkan pasien. Lebih dari itu kepercayaan diri dan empati dalam penanganan pasien juga menjadi indikator keberhasilan.

Hasil refleksi pada siklus I digunakan sebagai dasar untuk merencanakan tindakan pada siklus II yang terdiri atas: (1) menyusun kembali strategi perkuliahan berdasarkan hasil refleksi; dan (2) menyiapkan materi, lembar pengamatan, dan pertanyaan untuk sik- lus II. Pelaksanaan tindakan dilakukan dengan memimpin studi kasus dalam materi dan metode yang telah disepakati, serta menggunakan pendekatan Problem-Based Learning. Selama pelaksanaan tindakan, dilakukan pengamatan menggunakan lembar pengamatan untuk mengevaluasi antusiasme dan keaktifan peserta kuliah, dan memberi pertanyaan untuk mengungkap besarnya serapan mata kuliah selama siklus II. Refleksi dilakukan dengan jalan menganalisis hasil pengamatan, dan jawaban tertulis dari mahasiswa, mengevaluasi kelemahan dan kekuatan yang ada, dan mencari jalan keluar untuk mengatasi kelemahan tersebut. Demikian selanjutnya terjadi pengulangan kegiatan pada siklus III dengan materi dan metode yang semakin mendekati kriteria keberhasilan.

Instrumen penelitian terdiri atas kuesioner, lembar pengamatan, kuis dan catatan lapangan. Analisis data yang digunakan adalah analisis deskriptif kualitatif dengan memaknai apa yang terungkap dalam kuesioner, pengamatan, kuis, maupun wawancara. Kemampuan menangani pasien sebelum dan sesudah penerapan PBL diuji dengan metode judge oleh Dosen Pembimbing.

\section{HASIL PENELITIAN}

Pelaksanaan PKL Terapi Fisik dilaksanakan di Klinik Terapi Fisik FIKUNY, Rumah Sakit Panti Rapih, dan SLB Negeri Pembina Yogyakarta. PKL merupakan kerja mandiri di bawah bimbingan Dosen dan pembimbing dari tempat yang digunakan untuk PKL. Pada kegiatan ini mahasiswa diberi 
kesempatan menangani pasien secara langsung. Diskusi kasus diadakan di Klinik Terapi FIK, UNY setiap hari Jumat. Hasil penelitian pada setiap siklus tersaji sebagai berikut.

\section{Siklus I}

\section{Perencanaan}

Hasil diagnosis awal dengan cara wawancara mendalam menunjukkan, mahasiswa mempunyai motivasi belajar yang baik. Hal ini tampak dari antusiasme mahasiswa saat pembekalan dan observasi lapangan. Persepsi dan harapan mahasiswa tentang mata kuliah PKL Terapi Fisik antara lain bahwa mata kuliah PKL penting dalam menyiapkan mereka memasuki dunia kerja. Mereka juga mempersepsikan bahwa melalui PKL, mahasiswa dapat memperoleh pengalaman langsung menangani pasien, serta mampu menyusun, melaksanakan, dan mengevaluasi program yang berkaitan dengan kasus yang dihadapi.

Dalam upaya menyiapkan mahasiswa agar siap menangani kasus nyata di lapangan, pola pikir lama yang berangkat dari teori untuk kemudian diaplikasikan dalam menangani pasien perlu dibalik, yaitu mulai dari masalah nyata yang dihadapi, kemudian dipikirkan berbagai alternatif penyebab, dan kemungkinan jalan keluarnya. Pembelajaran berdasarkan masalah tampaknya dapat memenuhi persepsi dan harapan mahasiswa tersebut. Akhirnya Pendekatan Problem-Based Learning disepakati untuk diterapkan melalui presentasi kasus-kasus yang dianggap penting. Rencana materi yang akan digunakan sebagai sumber belajar meliputi te- rapi manipulatif misalnya cedera pergelangan kaki, cedera lutut, cedera panggul, cedera bahu, dan terapi latihan pada penyakit Diabetes Melitus, Artritis, Asma Bronchiale, dan hipertensi.

\section{Pelaksanaan Tindakan}

Diskusi kasus dilaksanakan dengan pendekatan Problem-Based Learning. Pada diskusi kasus pertama, diangkat masalah cedera panggul. Salah seorang mahasiswa memaparkan kasus cedera panggul dan penanganannya. Mahasiswa yang lain menanggapi, meminta konfirmasi, dan mengajukan pertanyaan yang berkaitan dengan kasus yang dibahas. Penyaji menjawab pertanyaan, termasuk mempraktekkan penanganan pada orang coba. Dosen sebagai fasilitator mengawasi jalannya diskusi supaya tetap dalam jalur yang benar. Sewaktu diskusi melenceng dari permasalahan, maka fasilitator akan meluruskan. Anggota tim peneliti yang lain sebagai kolaborator mengamati jalannya perkuliahan dengan lembar observasi dan catatan lapangan.

\section{Monitoring (Pengamatan)}

Berdasarkan lembar observasi tampak bahwa pada tahap awal, diskusi belum begitu lancar karena terbiasa kuliah satu arah. Mahasiswa masih kurang aktif dalam diskusi, hanya mahasiswa tertentu yang aktif. Peran dosen yang seharusnya hanya sebagai fasilitator masih agak dominan karena belum lancarnya proses diskusi.

Hal-hal yang terungkap dari catatan lapangan yaitu bahwa mahasiswa yang mempresentasikan kasus tidak sepenuhnya menguasai kasus yang di- 
bahas. Dalam presentasinya, penyaji tidak menyertakan kajian teori tentang kasus yang ditangani sehingga pengetahuan yang dapat digali kurang mendalam. Diskusi sempat macet dan dosen membantu dengan melontarkan pertanyaan tambahan terkait pertanyaan mahasiswa, untuk memancing diskusi lebih mendalam sekaligus untuk mengetahui serapan materi. Hambatan yang ada pada siklus ini terjadi akibat rendahnya rasa ingin tahu mahasiswa sehingga keaktifan kurang dan terkesan sekedar memenuhi kewajiban presentasi.

\section{Refleksi}

Pada tahap refleksi, tim peneliti bertemu untuk menganalisis hal-hal yang terungkap selama monitoring. Hasil pertemuan menyimpulkan bahwa pada tahap awal, mahasiswa belum sepenuhnya memahami teori dan konsep terkait materi yang disampaikan. Hal ini terlihat dari belum baiknya jalannya diskusi, tidak lengkapnya data presentasi kasus, dan belum tepatnya pemecahan masalah yang dihadapi.

Kriteria keberhasilan yang ditetapkan yaitu penguasaan ilmu dan keterampilan dalam menangani problem yang dikeluhkan pasien, meningkatnya kepercayaan diri dan empati dalam penanganan pasien belum tercapai. Selain itu pola pikir mahasiswa masih belum runtut. Pada akhir siklus I, mahasiswa menunjukkan sedikit perbaikan dalam keterampilan menangani kasus. Namun demikian untuk aspek pengetahuan masih sangat kurang. Kepada mahasiswa yang akan menampilkan kasus selanjutnya disarankan untuk menam- bah kajian teori terkait dengan kasus yang ditampilkan.

\section{Siklus II}

\section{Perencanaan}

Berdasarkan analisis dan refleksi siklus I, disusun perbaikan strategi penerapan PBL pada siklus II. Kasus yang akan dibahas diinformasikan pada pertemuan minggu sebelumnya. Penyaji disarankan untuk menyertakan kajian teori berkaitan dengan kasus yang dibahas, dan di akhir diskusi akan diadakan kuis untuk mengetahui serapan mahasiswa. Dengan strategi ini diharapkan semua mahasiswa siap, baik penyaji maupun peserta diskusi.

\section{Pelaksanaan Tindakan}

Pada siklus II disajikan kasus Hernia Nukleus Pulposus (HNP). Penyaji menyampaikan teori tentang HNP, yaitu definisi HNP, patofisiologi, dan penanganan HNP. Setelah itu ditampilkan penanganan kasus yang ditangani, yaitu seorang pasien laki-laki, usia 46 tahun, dengan keluhan saraf terjepit. Saat demonstrasi kasus, sebagai pengganti pasien dipakai teman mahasiswa yang lain. Dilaporkan, kondisi awal pasien tidak bisa berdiri tegak, posisi badan condong ke kanan, nyeri pinggang bawah, dan rasa nyeri terasa sampai paha bagian belakang. Penanganan yang dilakukan, yaitu pelemasan otot sekitar pinggang yang sakit, pelemasan otot pantat dan paha belakang $(m \cdot g l u-$ teus dan m.hamstring) dengan teknik pijat effleurage dan friction. Setelah itu, dilakukan pengecekan cedera, pelemasan ototulangan, dan ditutup dengan effleurage. Perkembangan pasien cukup meng- 
gembirakan, karena setelah terapi ke-5 kondisi pasien sudah bisa dikatakan baik.

Sesudah presentasi selesai, dibuka forum tanya jawab untuk memperdalam diskusi. Seorang mahasiswa menanyakan bagaimana cara mengetahui bahwa keluhan pasien tersebut adalah HNP, kemudian penyaji menjawab bahwa nyeri pinggang bawah terbanyak disebabkan oleh HNP. Jawaban tersebut menurut fasilitator belum tepat, karena banyak keluhan yang serupa dengan apa yang dirasakan oleh pasien, tetapi bukan HNP. Harus dipahami bahwa tidak semua nyeri pinggang bawah adalah gejala HNP. Namun, setiap HNP memberi gejala nyeri pinggang bawah. Selanjutnya diskusi dilanjutkan dengan tanya jawab lagi seputar topik HNP. Beberapa kali penyaji diminta mendemonstrasikan cara menangani pasien HNP.

Seorang peserta menyampaikan kasus serupa yang pernah ditangani dan bagaimana penanganan pasien waktu itu. Pasien mengeluh nyeri pinggang kiri karena mengangkat beban berat, dan pekerjaan pasien adalah pengangkut buah-buahan. Setelah diterapi, keluhan pada pinggang kiri berkurang, tetapi nyeri seperti berpindah ke sebelah kanan, bahkan nyeri terasa dari pinggang sampai ke paha kanan. Persoalan ini kemudian dibahas diantara peserta diskusi. Ada yang menjawab, menyanggah, mengklarifikasi dan melengkapi. Fasilitator membimbing diskusi sehingga masalah HNP dibahas dari berbagai aspek. Di akhir diskusi disimpulkan bahwa ciri khas nyeri pada HNP tidak sekedar lokal di pinggang, tetapi ada penjalaran nyeri sampai kaki bahkan sampai telapak kaki.

\section{Monitoring}

Dari panduan observasi mengenai respon peserta saat kegiatan berlangsung, tercatat 3 peserta bertanya, 1 peserta meyanggah. 1 peserta mengklarifikasi sekaligus melengkapi jawaban peserta, 6 peserta tertawa tepat waktu, dan tidak ada peserta yang mengantuk maupun acuh tak acuh. Pola pikir masih terbatas dari teori ke kasus, meskipun bahasan sudah lebih luas karena kajian teori telah dilakukan. Hal ini terlihat dari hasil diskusi yang sudah sampai pada kesimpulan: apa dan bagaimana HNP. Hasil kuis memperlihatkan bahwa serapan mahasiswa tentang materi masih belum optimal. Namun demikian, sikap dan empati terhadap pasien sudah baik, terlihat dari perlakuannya terhadap orang coba sewaktu memperagakan penanganan. Penyaji memperlakukan orang coba seperti layaknya saat menghadapi pasien yang sesungguhnya.

\section{Refleksi}

Tim peneliti mengadakan pertemuan untuk menganalisis dan melakukan refleksi terkait dengan hasil monitoring siklus II. Berdasarkan catatan lapangan, terlihat bahwa diskusi sudah berjalan lancar, mahasiswa terlihat antusias mengikuti diskusi. Pada siklus ini peran fasilitator masih besar, walaupun sudah berkurang dibandingkan siklus pertama. Fasilitator tidak sekedar menjaga supaya diskusi berjalan lancar dan tidak keluar dari topik yang dibahas, tetapi juga menerangkan seluk beluk 
kasus berdasarkan pertanyaan yang berkembang selama diskusi. Hal ini mungkin terjadi karena jawaban mahasiswa masih terbatas, dangkal, dan kadang kurang tepat. Selain itu, kajian teori yang dipakai sebagai pendukung paparan kasus hanya bersumber dari buku teks. Dari pengamatan terlihat bahwa mahasiswa baru dalam taraf berbagi pengalaman, belum berbagi teori.

Saling berbagi informasi antarmahasiswa seharusnya tidak sekedar berbagi pengalaman tetapi harus disertai teori dan konsep dari sumber-sumber yang mutakhir, misalnya dari internet. Demikian juga dengan penggunaan alat peraga yang belum banyak dimanfaatkan oleh mahasiswa. Terkait dengan kriteria keberhasilan yang akan dicapai, pada akhir siklus II semakin tampak mendekati kriteria tersebut. Teori dan konsep mulai tertata baik, walaupun penguasaan materi masih terbatas. Aspek sikap dan empati sudah cukup baik. Namun demikian, keterampilan penanganan pasien masih kurang karena butuh perawatan $5 x$ sampai terjadi perbaikan. Hasil siklus II dirasa belum optimal dan selanjutnya tim peneliti sepakat untuk mengadakan siklus III.

\section{Siklus III}

\section{Perencanaan}

Berdasarkan refleksi pada siklus II disusun strategi pembelajaran dengan mengoptimalkan media, alat peraga, dan penyempurnaan materi yang didiskusikan. Penyaji menyiapkan kasus yang disepakati untuk dibahas dengan lebih baik. Sumber-sumber belajar dioptimalkan, terutama sumber dari in- ternet, baik studi kasus sejenis maupun dari jurnal-jurnal. Pada siklus ini direncanakan dibagikan angket untuk mengetahui penilaian mahasiswa terhadap kegiatan pembelajaran.

\section{Pelaksanaan Tindakan}

Kasus pada siklus III membahas tentang cedera sendi bahu. Antusiasme mahasiswa dalam mengikuti perkuliahan terlihat meningkat. Penyaji mempresentasikan kasus dengan baik, alat peraga berupa gambar dan atlas digunakan. Partisipasi tiap mahasiswa cukup baik. Diskusi berkembang baik, dan permasalahan bisa dibahas dari berbagai sudut pandang pemecahan masalah.

Saat terjadi diskusi, kebetulan ada peserta yang mengalami dislokasi sendi bahu. Penyaji langsung menangani kasustersebut. Awalnya dilakukan tes berbagai gerakan standar sendi bahu untuk keperluan diagnosis. Setelah dipastikan bahwa terjadi dislokasi sendi bahu dilakukan penanganan dengan terapi manipulatif (massage). Pijatan dilakukan mulai dari punggung tangan, terus ke atas sampai bahu, dan diteruskan sampai leher. Setelah itu dilakukan pijatan pada lengan, dalam berbagai posisi. Pada akhir terapi dilakukan traksi ke bawah, kemudian lengan diputar ke belakang dan ke depan, dan diakhiri dengan efflurage penutup sebagai sentuhan akhir. Pada akhirnya dilakukan tes kembali untuk mengecek apakah bahu sudah bisa digerakkan sesuai dengan standar gerakan sendi bahu. Ternyata dalam 20 menit semua gerakan standar sendi bahu sudah bisa di- 
lakukan oleh orang coba tanpa rasa nyeri.

\section{Monitoring (Pengamatan)}

Berdasarkan lembar pengamatan dan catatan lapangan, pada siklus III semakin tampak bahwa kemampuan mahasiswa dalam menangani pasien semakin meningkat. Penyajian kasus sudah menyertakan sumber pustaka dari internet sehingga wawasan mahasiswa semakin luas. Partisipasi mahasiswa dalam diskusi sudah baik. Diskusi berjalan lancar dan banyak permasalahan terkait cedera bahu dibahas.

Keterampilan mahasiswa dalam menangani pasien menunjukkan peningkatan. Hal ini tampak saat penyajian kasus dan penanganan kasus yang sesungguhnya. Penyaji bisa menangani kasus cedera bahu dengan baik, dan dalam waktu sekitar 20 menit sudah terlihat hasil terapi. Sikap dan empati dalam menangani pasien sangat baik. Pemijat berusaha supaya pasien tidak terlalu sakit saat diterapi. Kajian teori yang diambil dari kasus serupa di tempat lain sangat membantu, meskipun ada perbedaan alat yang digunakan. Umumnya di Rumah Sakit digunakan fisioterapi dengan pemanas atau alat elektrik lain. Dari penyajian ini timbul rasa ingin tahu mahasiswa tentang jenis terapi yang lain, misalnya fisioterapi dengan sinar infra merah.

Dari angket yang berisi penilaian peserta terhadap proses kegiatan diketahui bahwa sebagian besar mahasiswa menilai proses dalam kategori sangat baik, dan menganggap tinggi relevansi antara materi dengan problem di lapangan. Demikian juga mahasiswa menganggap adanya kelayakan skenario problem sebagai pemicu belajar. Dukungan fasilitator untuk menimbulkan inspirasi, inovasi, dan dorongan dalam mempraktekkan keterampilan dinilai sangat tnggi oleh mahasiswa. Penggunaan media dan alat peraga dianggap sudah memadai untuk membantu meningkatkan pemahaman mahasiswa.

\section{Refleksi}

Tim peneliti bertemu kembali untuk menganalisis hasil siklus III. Kriteria keberhasilan yang ditetapkan yaitu penguasaan ilmu dan keterampilan dalam menangani problem yang dikeluhkan pasien, kepercayaan diri dan empati dalam penanganan pasien dinilai sudah optimal. Kemampuan mahasiswa dalam memecahkan masalah sudah dinilai memadai, baik dari sisi pemanfaatan pengetahuan tentang terapi fisik, keterampilan penanganan, maupun sikap terhadap pasien. Teknik massage telah dikuasai dengan baik, dan sudah diorientasikan pada tujuan untuk menyembuhkan pasien. Pola pikir sudah mulai runtut, lebih terbuka terhadap berbagai alternatif, dan telah berbalik arah dari kasus ke teori dan ke kasus kembali. Mahasiswa menjadi terbiasa belajar dari kasus kemudian muncul berbagai alternatif penyebab dan menemukan jalan keluar dengan bantuan dari berbagai kajian teori dan konsep.

Strategi penerapan Problem-Based Learning pada siklus III tampaknya mampu meningkatkan kualitas pembelajaran PKL Terapi Fisik. Hal ini terlihat dari tercapainya indikator keberhasilan yaitu mencakup berkembangnya pe- 
ngetahuan mahasiswa tentang terapi fisik, meningkatnya keterampilan dalam menangani pasien, dan berkembangnya sikap serta empati yang baik terhadap pasien. Berdasarkan kondisi ini, diputuskan oleh tim peneliti untuk berhenti pada siklus III karena sasaran pembelajaran dianggap telah tercapai, dan strategi penerapan PBL telah ditemukan.

\section{PEMBAHASAN}

Denganditerapkannya strategi pembelajaran Problem-Based Learning pada mata kuliah PKL Terapi Fisik, mahasiswa mampu berpikir kritis dan menyeluruh dalam memecahkan masalah nyata di lapangan. Mahasiswa juga mampu memahami berbagai konsep dasar yang menjadi pegangan untuk memecahkan masalah, serta lebih siap untuk terjun di lapangan pekerjaan. Hal tersebut sesuai dengan yang digambarkan oleh Wood (2004:2) bahwa dalam PBL, pembelajar didorong untuk menggabungkan berbagai informasi. Pada tahap awal perlu mengecek apakah informasi yang mereka dengar atau baca itu benar dan mencoba untuk menggabungkan informasi baru dengan pengetahuan yang sebelumnya sudah mereka miliki (konsolidasi). Dengan kemampuan konsolidasi mahasiswa lebih percaya diri tentang apa yang sudah mereka pahami dan dapat berbagi dengan teman lain atau bahkan dapat mengembangkannya.

Dalam penelitian ini, mahasiswa dikelompokkan dalam kelompok kecil dan dihadapkan pada suatu masalah. Kelompok kecil disupervisi oleh fasilitatoryangtugasnya mengarahkan, mem- beri saran, dan menjaga diskusi tetap dalam jalur yang benar, tetapi tidak mensuplai informasi. Keadaan ini belum dimungkinkan pada siklus I dan II karena terjadi kemacetan diskusi apabila tidak ada tambahan informasi. Setelah dari kelompok kecil, mahasiswa mempresentasikan dan mendemonstrasikan penanganan pasien ke kelompok besar.

Problem-Based Learning efektif dilakukan dalam kelompok kecil untuk mencapai pengalaman belajar yang optimal bagi seluruh anggota kelompok. Dengan kelompok kecil, dimungkinkan aktifnya seluruh anggota kelompok. Hal ini sejalan dengan pemikiran Paulina (2001:26) bahwa pendekatan Problem-Based Learning pada dasarnya merupakan pendekatan belajar aktif dalam pengelolaan sistem pembelajaran menuju cara belajar mandiri. Belajar yang bermakna terjadi bila mahasiswa berperan secara aktif dalam proses belajar dan akhirnya mampu memutuskan apa yang akan dipelajari dan cara mempelajarinya. Peran serta mahasiswa dan dosen dalam belajar aktif menjadi sangat penting. Dosen berperan aktif sebagai fasilitator yang membantu memudahkan mahasiswa dalam belajar. Dosen berperan sebagai nara sumber yang mampu mengundang pemikiran dan daya kreasi mahasiswa. Dosen juga sebagai pegelola yang mampu merancang dan melaksanakan kegiatan belajar, dan dapat mengelola sumber belajar yang diperlukan. Mahasiswa juga terlibat dalam proses belajar bersama dosen, karena mahasiswa dibimbing, diajar, dan dilatih menjelajah, mencari, mempertanyakan sesuatu, me- 
nyelidiki jawaban atas pertanyaan, mengelola, dan menyampaikan hasil perolehannya secara komunikatif.

Hasil penelitian menunjukkan bahwa dari satu kasus ke kasus berikutnya ada peningkatan kualitas pembelajaran yang cukup signifikan, baik dari segi proses maupun hasil yang menunjukkan adanya perubahan perilaku. Secara proses, jalannya perkuliahan berlangsung semakin lancar, diskusi lebih hidup, dan tercipta dinamika kelompok yang semakin membaik. Rasa ingin tahu mahasiswa meningkat, ada peningkatan efektivitas dalam berbagi informasi berdasarkan kajian pustaka dan pengalaman disertai meningkatnya kemampuan mahasiswa dalam memikirkan berbagai alternatif penyebab dan pemecahan masalah. Dari sisi produk, di akhir siklus III penguasaan mahasiswa dalam bidang terapi fisik meningkat secara signifikan. Hal ini terungkap dari ketepatan mahasiswa dalam menangani kasus, menyangkut ketepatan diagnosis, tindakan, dan sikap terhadap pasien, termasuk keterampilan menangani kasus dalam waktu 20 menit. Hasil penelitian ini relevan dengan teori belajar aliran tingkah laku yang dikemukakan oleh Prasetya Irawan (1994:31) yaitu bahwa pada dasarnya belajar adalah perubahan dalam tingkah laku sebagai akibat dari interaksi antara stimulus dengan respon. Perubahan tingkah laku ini dapat berwujud sesuatu yang dapat diamati dan tak dapat diamati.

Baik bagi fasilitator maupun mahasiswa, keterampilan mendengarkan, berbicara, dan tukar pendapat merupakan kunci keberhasilan PBL. Semua anggota kelompok diharapkan berpartisipasi. Fasilitator mendorong siswa untuk mengawali diskusi, mengajukan pertanyaan, mempertanyakan suatu pernyataan dan menanyakan untuk klarifikasi. Hal ini dilakukan untuk menimbulkan rasa ingin tahu. Fasilitator bertugas mengatur kelompok tanpa memperlihatkan dominasi dan bahkan kelompok harus dapat berfungsi secara efektif walaupun tanpa kehadiran fasilitator dengan penambahan kemampuan kognitif yang signifikan. Prinsip ini sesuai dengan teori belajar aliran kognitif yang lebih mementingkan proses belajar dari pada hasil belajar itu sendiri. Belajar tidak hanya melibatkan hubungan antara stimulus dan respon, namun melibatkan proses berpikir yang lebih kompleks. Perhatian lebih terpusat pada bagaimana suatu ilmu yang baru berasimilasi dengan ilmu yang sebelumnya sudah dikuasai. Menurut teori ini ilmu pengetahuan dibangun dalam diri seorang individu melalui proses interaksi yang berkesinambungan dengan lingkungan. Proses ini tidak berjalan terpatah-patah, melainkan mengalir, bersambung-sambung dan menyeluruh.

Jean Piaget sebagai salah satu penganut aliran kognitif yang kuat membagi proses belajar menjadi tiga tahap yaitu proses asimilasi, akomodasi, dan equilibrasi. Proses asimilasi merupakan proses penyatuan informasi baru ke struktur kognitif yang sudah ada. Akomodasi merupakan proses penyesuaian struktur kognitif ke dalam situasi yang baru, sedangkan equilibrasi adalah penyesuaian berkesinambungan antara asimilasi dam akomodasi. Dua orang yang 
mempunyai jumlah dan jenis informasi yang sama, dapat mempunyai persepsi yang berbeda tergantung dari kemampuan equilibrasinya. Seseorang dengan kemampuan equilibrasi yang baik akan mampu menata berbagai informasi ini dalam urutan yang baik, jernih dan logis, sebaliknya mereka dengan kemampuan equilibrasi yang kurang baik akan cenderung menyimpan semua informasi yang ada secara kurang teratur sehingga alur berpikir menjadi ruwet, tidak logis dan berbelit-belit.

Pada penelitian ini, masalah yang dibahas berasal dari kasus-kasus yang ditemukan mahasiswa sewaktu praktek lapangan. Pada siklus pertama presentasi kasus yang ditampilkan masih belum baik. Selanjutnya, pada siklus II diperbaiki, yaitu dengan menginformasikan kasus yang akan dibahas disertai kajian teori yang komprehensif terkait dengan kasus yang ditelaah, dan pada siklus III penyajian materi dilengkapi dengan media dan alat peraga, disertai penggunaan berbagai sumber belajar, termasuk internet, dan belajar dari kasus-kasus serupa. Di sini terlihat bahwa penerapan strategi Problem-Based Learning pada mata kuliah PKL Terapi Fisik memerlukan beberapa tahap sampai tercapai kriteria keberhasilan yang diinginkan.

Hasil penelitian juga menunjukkan bahwa dengan belajar berdasarkan masalah mahasiswa menjadi lebih aktif terlibat dalam proses belajar. Hal ini sejalan dengan pendapat Wood (2004), yaitu bahwa belajar secara aktif mempunyai banyak keuntungan, karena dapat dipelajari beberapa keterampilan sekaligus, seperti misalnya keterampilan bekerja dalam tim, memformulasikan masalah, menemukan informasi, membuat keputusan, dan lainlain. Selain itu, pola pikir yang selama ini terbiasa dengan wawasan yang sempit menjadi lebih terbuka, yaitu pola pikir yang berawal dari masalah yang dihadapi, dipikirkan berbagai alternatif penyebab, dan menemukan jalan keluarnya. Hal ini pada akhirnya melatih mahasiswa untuk dapat berpikir kritis dan menyeluruh dalam memecahkan masalah. Dengan kemampuan berpikir kritis, mahasiswa menjadi lebih percaya diri untuk terjun ke dunia kerja.

Salah satu tujuan pendekatan Problem-Based Learning adalah meningkatkan motivasi pembelajar untuk mengkaji sesuatu. Dosen seringkali berasumsi bahwa motivasi belajar mahasiswa merupakan masalah mahasiswa itu sendiri, dan mahasiswa lah yang bertanggung jawab untuk mengusahakan agar mempunyai motivasi yang tinggi. Sebenarnya, dosen dapat berusaha untuk menerapkan prinsip-prinsip motivasi dalam kegiatan mengajarnya. Ada empat kategori kondisi motivasional yang perlu diperhatikan oleh dosen, yaitu: (1) perhatian (attention); (2) relevansi (relevance); (3) kepercayaan diri (self confidence); (4) kepuasan (satisfaction). Perhatian mahasiswa muncul karena dorongan rasa ingin tahu. Oleh karena itu rasa ingin tahu ini perlu mendapat rangsangan sehingga mahasiswa akan memberikan perhatian dan perhatian tersebut harus tetap terpelihara selama perkuliahan. Rasa ingin tahu ini dapat dirangsang melalui elemen-elemen yang baru, aneh, lain dengan yang su- 
dah ada, kontradiktif, atau kompleks. Meskipun demikian penggunaan stimulus tak boleh berlebihan agar tidak kehilangan efektivitasnya.

Relevansi pada perkuliahan menunjuk pada hubungan antara materi perkuliahan dengan kebutuhan dan kondisi mahasiswa. Motivasi mahasiswa akan terpelihara apabila mereka menganggap apa yang dipelajari memenuhi kebutuhan pribadi, atau bermanfaat dan sesuai dengan nilai yang dipegangnya. Kepercayaan diri mahasiswa untuk melakukan suatu tugas yang menjadi syarat keberhasilan akan menimbulkan motivasi.

\section{KESIMPULAN}

Dari hasil penelitian dan pembahasan yang telah diuraikan, dapat disimpulkan bahwa strategi penerapan Problem-Based Learning pada mata kuliah PKL Terapi Fisik dimulai dengan mengangkat kasus nyata yang dihadapi mahasiswa sewaktu melaksanakan PKL. Setelah dipilih satu kasus, kemudian dilakukan kajian teori mengenai kasus tersebut baik dari buku teks maupun dari hasil kajian mengenai kasus serupa. Internet dapat menjadi sarana yang sangat membantu. Kasus yang telah dilengkapi dengan kajian teoritis tersebut selanjutnyadipresentasikan untuk dikritisi baik dari segi ketepatan diagnosa, keefektifan terapi, maupun keberlanjutan rehabilitasi. Diperlukan kesiapan seluruh peserta diskusi untuk mendengar, merefleksi, dan mengungkapkan secara logis dan sistematis.

Dari kasus yang telah dipresentasi dan dikritisi, ditarik kembali konsepkonsep teoritis penting terkait dengan kasus tersebut. Dengan demikian, strategi penerapan PBL akan efektif bila terjadi pemikiran bolak-balik antara kasus-teori-pengalaman dan kembali ke kasus lagi. Begitu seterusnya sehingga semakin terbuka pemikiran mahasiswa dalam memandang kasus dan mencari jalan keluar dari kasus tersebut berdasarkan pemikiran logis baik se cara teoritis maupun empiris.

Penerapan PBL akan memberi hasil berupa pengayaan teori sekaligus keterampilan untuk memanfaatkan teori dalam menangani kasus nyata di lapangan dengan waktu yang lebih singkat. Meskipun demikian disadari bahwa untuk bisa melaksanakan PBL diperlukan kesiapan teori yang cukup dan kemauan untuk aktif mengeksplorasi teori maupun pengalaman orang lain terkait dengan kasus tersebut. Dengan demikian dapat dikatakan bahwa PBL akan lebih efektif apabila diterapkan pada matakuliah di semester atas yang terkait dengan penyiapan profesi, seperti pada matakuliah Praktek Kerja Lapangan. Dalam matakuliah PKL dimungkinkan jumlah mahasiswa yang kecil karena dibagi dalam beberapa peminatan, dan hal ini merupakan salah satu faktor penentu dalam keberhasilan penerapan PBL. Kesimpulan akhir dapat dikatakan bahwa pendekatan PBL sangat tepat untuk diterapkan dalam matakuliah PKL Terapi Fisik.

\section{UCAPAN TERIMA KASIH}

Pada kesempatan ini perkenankan saya menghaturkan terimakasih kepada Direktur DP2M Dikti yang memberi dana lewat Program Penelitian Research Based Teaching yang masuk dalam dana 
DIPA Universitas Negeri Yogyakarta tahun2007. Ucapan terimakasih juga saya sampaikan kepada Rektor UNY melalui Ketua Lembaga Penelitian UNY yang telah berkenan menyetujui dan memfasilitasi penelitian ini baik dari segi keuangan maupun administrasi. Tak lupa ucapan terimakasih juga saya sampaikan kepada sejawat dr. Rahmah Laksmi Ambardini, M.Kes. yang membantu secara intensif penelitian ini dan mengijinkan saya untuk mempublikasikan penelitian ini secara mandiri. Kepada para mahasiswa prodi IKORA FIK-UNY yang mengambil mata kuliah PKL pada tahun 2007, saya ucapkan terima kasih atas keikhlasan anda belajar bersama saya dengan cara baru. Harapan saya semoga penelitian ini baik pada proses maupun hasil memberi banyak manfaat kepada para mahasiswa yang terlibat, dan bagi pengembangan matakuliah Praktek Kerja Lapangan dalam fungsinya sebagai mata kuliah penyiapan profesi.

\section{DAFTAR PUSTAKA}

Alessio, HM. 2002. "Student Perception About and Performance in ProblemBased Learning". dari http://www.mcli.dist.maricopa.edu. Diakses pada tanggal 15 Juli 2006.

Barrows., 2001. "The Tutors (Teachers) Role in Problem-Based Learning Curriculum". dari http;// edaff.siumed.edu. Diakses pada tanggal 15 Juli 2006.
Davies, Ivor K. 1997. The Management of Learning. London: Mc Graw-Hill Book Company.

Gagne, Robert M. 1985. The Condition of Learning and Theory of Instruction. New York: Holt, Rinehart \& Winston.

Kelsner., 2001. "PBL in Areas outside of Medicine". dari http;/Wwww.mcli.dist.maricopa.edu. Diakses pada tanggal 15 Juli 2006.

Middlebex University., 2002. Project on the Effectiveness of Problem Based Learning (PBL): "Project Summary Teaching and Learning Research Programed". dari http://www.hebes.mdx.ac.uk/teaching/ Reseach/PEBL/index.htm. Diakses pada tanggal 17 Oktober 2007.

Mierson., 2004. "A Problem-Based Learning Course in Physiology for Undergraduate and Graduate basic Science Student"s. dari http://edaff.siumed.edu. Diakses pada tanggal 15 Juli 2006.

Paulina Pannen dkk. 2001. Konstruktivisme dalam Pembelajaran. Jakarta: Ditjendikti, Depdiknas.

Prasetya Irawan dkk. 1994. Teori Belajar, Motivasi, dan Keterampilan Mengajar. Jakarta: Ditjendikti, Depdikbud.

Thornburg, Hershell D. 1984. Learning Theory, Instruction Psychology; 
108

St Paul: West Publishing Company

Wood EJ., 2004. "Problem-Based Learning: Exploiting Knowledge of How
People Learn to Promote Effective Learning". dari http:/bio.itsn.ac.uk/journal/vol3. Diakses pada tanggal 17 Oktober 2007. 